研究ノート

[環境化学 (Joumal of Environmental Chemistry) Vol. 5, No. 1, pp. 87- 93, 1995]

\title{
仙台市内の代表的な土壌に打ける酸中和能調査
}

\author{
口田 圭吾, 佐藤 慎二, 千葉 恵, 玉川 勝美 \\ 加藤 丈夫，小場 正彦 \\ 仙台市衛生研究所 \\ （９83 仙台市若林区卸町東2-5-10）
}

[平成 6 年 9 月 1 日受理］

\section{Investigation of Acid-neutralizing Capacity of Some Representative Soil Samples in Sendai City}

\author{
Keigo KUCHIDA, Shinji SATO, Megumi CHIBA, Katsumi TAMAKAWA \\ Takeo KATO and Masahiko OBA \\ Sendai Municipal Institute of Public Health \\ (2-5-10, Oroshimachi Higashi, Wakabayashi-ku, Sendai 983)
}

[Received September 1, 1994]

\begin{abstract}
Acid-neutralizing capacity was measured by the batch technique on fifteen kinds of soil type collected in Sendai City in order to investigate the damage against plants by acid rain. Measurement items are $\mathrm{pH}, \mathrm{EC}$ and acid-neutralizing capacity of the soils. The acid-neutralizing capacity is defined as $\mathrm{H}^{+}$volume being consumed by $100 \mathrm{~g}$ of soil until $\mathrm{pH}$ of soil pore water decreases as low as 4.7. Also the composition of water soluble cations of soil was compared each other by "similarity (of patterns)".

The $\mathrm{pH}\left(\mathrm{H}_{2} \mathrm{O}\right)$ of 15 soil types ranged from 4.5 to 7.5 . The similarity of cation was close for lower layer of all soil types except for one soil type (article soil). The ANC of each soil ranged from 0.1 to 33.9 (meq/100g), and the average was 13.2 (meq/100g). Also, the range of upper layers' ANC was 1.2 to 29.5 (meq/100g) with an average 14.3 (meq/100g). Soil type that showed the lowest ANC was sand hill immature soil collected at 'Fukanuma (sand beach)', and the highest ANC soil type was the ash yellow soil collected at 'Imozawa Kita'.
\end{abstract}

Key words: acid-neutralizing capacity, rain water, soil, similarity of patterns

\section{1. はじめに}

近年, 欧米において酸性の雨によると思われる森林の 衰退, 湖沼の酸性化などが問題となっている ${ }^{1 !} 。$ 環境庁 が昭和58年度から62年度に実施した第 1 次酸性雨対策調 査結果によると, わが国の場合, 酸性雨による生態への 影響は顕在化していないとされた。しかしながら, 関東 地方におけるスギ枯れ等のような, 近年のわが国におけ る森林の衰退は酸性雨などの影響によるものであるとい
う報告もなされている2!。土壤の酸性化は，カリウム， カルシウム, マグネシウムなどの植物養分の溶脱を促進 するとともに，アルミニウム，銅，マンガンなどの植物 の生育に有害な金属イオンの溶出を促進させる3!。

酸性物質の年間沈着量が欧米と同程度のわが国で, 被 害が顕在化しない理由の一つとしては, 酸性降下物に対 する土㙵の酸中和能（以下，土㙵中和能）の相違が考え られてきだ)。しかしながら, わが国では環境庁水質保 全局と日本土壤肥料学会が昭和58年に「酸性雨の土壤へ 
の影響予察図」 ${ }^{5)}$ を作成したものの, 土壤中和能の実態 調査は十分に行われていないのが現状である。また，土 壤型により土壤中和能が大きく異なることも報告されて いる ${ }^{6-7)}$ 。従来, 土壤中和能の測定は土壤をカラムに充 填し，模擬酸性雨を滴下する方法により測定しており， 非常に煩雑であり，結果を得るまでに長期間を要してい た。佐藤・大岸6) は土壤中和能を測定するための簡便な バッチ法を開発し，カラム法との比較において高い相関 を報告している。

そこで，本研究では仙台市内に比較的広範に存在する 15種類の土壤型について，それぞれの土壌中和能を佐 藤・大岸6) の開発したバッチ法により測定し，本市にお ける酸性雨による被害の予測を試みた。

\section{2. 調查方法}

\section{1 土境採取地点}

経済企画庁発行の仙台土壤罒 ${ }^{8)}$ ならびに宮城県発行の 川崎・山形土壤図 ${ }^{91}$ に基づき, 仙台市内の 15 地点, 15種 類の土壤型において土壤試料の採取を行った。採取地点 の選定にあたっては，(1)酸性雨の植物への影響調査を目 的としていることから, 植生が認められる林内とするこ と, (2)近辺に特定の公害発生源がないこと, などに留意 した。採取地点, 採取した土壤の土堙型などを図 1 およ び表 1 に示した。

\section{2 土墥採取方法}

各地点では，地表の落葉を除去し土壤表面を露出させ た後，深さ約 $1 \mathrm{~m}$ までの土壤を地層別に約 $2 \mathrm{~kg}$ づつ採 取した。なお，土壤試料の採取中に岩盤あるいは碟層ま で到達した場合には，その直前までの層を試料とした。 実験室に搬入後, 土壤試料をよく混合し， $2 \mathrm{~mm}$ のフル イを通過させ，礫や植物の根などを除去し，風乾した。 これを風乾土としてサンプル瓶に保存し, 分析に供した。

\section{3 調查項目および分析方法}

\section{3. $1 \mathrm{pH}\left(\mathrm{H}_{2} \mathrm{O}\right)$ および電気等奄率}

$\mathrm{pH}\left(\mathrm{H}_{2} \mathrm{O}\right)$ は，風乾土 $10 \mathrm{~g}$ に超純水 $25 \mathrm{ml}$ を加えた後かき 混ぜ， 1 時間放置したものを，測定前に軽くかき混ぜ懸 濁状態とし，ガラス電極法により測定した。電気導電率 （EC）は風乾土 $10 \mathrm{~g}$ に超純水 $50 \mathrm{ml}$ 添加し，60分振り混せ た後，懸濁液を導電率計の電極に浸して測定した ${ }^{10)}$ 。 なお，使用した $\mathrm{pH}$ 計ならびに導電率計は東垔電波工業 製の HM-30S，CM-60S である。

\section{3. $2(\mathrm{ANC}) \mathrm{c}$ 測定法}

風乾土壤 $1 \mathrm{~g}$ に $0.5 \mathrm{~mol} / 1$ の酢酸一酢酸アンモ二ウム緩 衝液 $\left(\mathrm{pH} 4.7\right.$ )を $50 \mathrm{ml}$ 加え， $25^{\circ} \mathrm{C}$ に保たれた恒温室で 24 時 間振とうした。土壤と溶液を遠心分離 $(3,500 \mathrm{rpm}, 10$ 分間）した後，ポアサイズ $0.45 \mu \mathrm{m}$ のディスミックフィ ル夕ーで上澄み液をろ過した。ろ液の $\mathrm{Na}^{+}, \mathrm{K}^{+}, \mathrm{Ca}^{2+}$

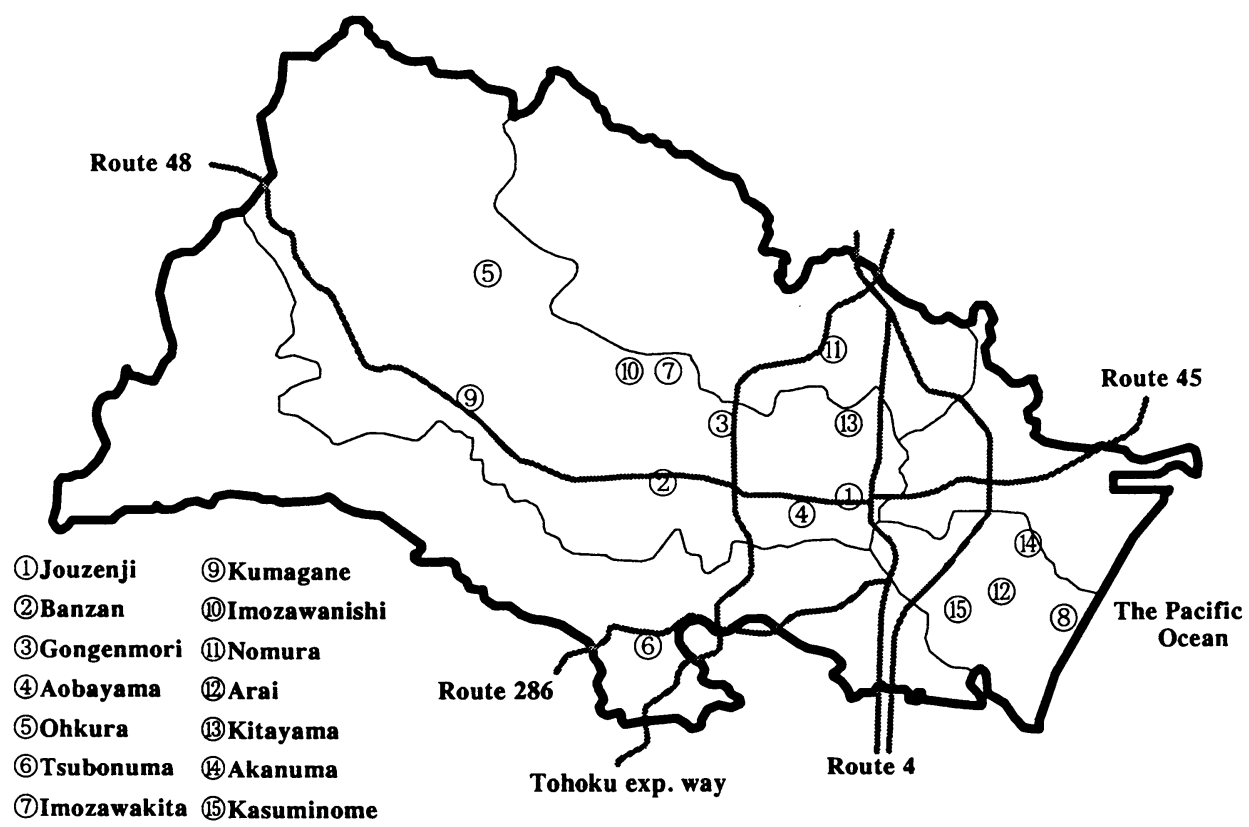

(8)Fukanuma

Fig. 1 Monitoring point of 15 soil types in Sendai City 
Table 1 Type of soil and vegetation at each monitoring point

\begin{tabular}{|c|c|c|}
\hline $\begin{array}{l}\text { Monitoring } \\
\text { point }\end{array}$ & Type of soil & Vegetation \\
\hline Jozenji & Article soil & Zelkova serrata (Thunb.) Makino \\
\hline Banzan & Brown forest soil & Quercus serrata Murray \\
\hline Gongenmori & $\begin{array}{l}\text { Brown forest soil } \\
\text { (sand type) }\end{array}$ & $\begin{array}{l}\text { Pinussp, Castanea mollisina } \\
\text { xC.crenata }\end{array}$ \\
\hline Aobayama & $\begin{array}{l}\text { Brown forest soil } \\
\text { (circular stone type) }\end{array}$ & Pinussp, Quercus serrata Murray \\
\hline Ohkura & Brown forest soil(dry) & $\begin{array}{l}\text { Cryptomeria japonica D.Don, } \\
\text { Chamaecyparis obtusa Endl }\end{array}$ \\
\hline Tsubonuma & Red and yellow soil & Quercus serrata Murray \\
\hline Imozawakita & Brown lowland soil & Cryptomeria japonica D.Don \\
\hline Fukanuma & Sand dune regosol & Pinus thunbergii Parl \\
\hline Kumagane & Black soil & Cryptomeria japonica D.Don \\
\hline Imozawanishi & Gray lowland soil & Cryptomeria japonica D.Don \\
\hline Nomura & Gray upland soil & Cryptomeria japonica D.Don \\
\hline Arai & Gley soil & Cryptomeria japonica D.Don \\
\hline Kitayama & Strong gley soil & Pinus densiflora Sieb.et Zucc \\
\hline Akanuma & Muck soil & Cryptomeria japonica D.Don \\
\hline Kasuminome & Peat soil & Cryptomeria japonica D.Don \\
\hline
\end{tabular}

および $\mathrm{Mg}^{2+}$ を定量した。緩衝液の代わりに超純水を用 いて水溶性の $\mathrm{Na}^{+}, \mathrm{K}^{+}, \mathrm{Ca}^{2+}$ および $\mathrm{Mg}^{2+}$ の量を求め, 先の定量值からそれぞれ差し引いた。各イオンについて 土壤 $100 \mathrm{~g}$ あたりのミリ当量 $(\mathrm{meq})$ で表し, それらの総和 を( ANC) c とした。 $\mathrm{Na}^{+}$および $\mathrm{K}^{+}$は原子吸光法により， $\mathrm{Ca}^{2+}$ および $\mathrm{Mg}^{2+}$ はイオンクロマトグラフ法によりそ れぞれ定量した。

使用したイオンクロマトグラフ装置は横河電機製の IC-500P, 陽イオン分析用のカラムはICS-C25, 陰イオ ン分析用のカラムはSAM3-125である。

\section{3. 3 (ANC) a 測定法}

風乾土壤 $1 \mathrm{~g} に 1.56 \times 10.3 \mathrm{~mol} / 1$ 硫酸カリウム溶液を $50 \mathrm{ml}$ 加之，懸濁液の $\mathrm{pH}$ が正確に4.70になるように $1 \mathrm{~mol} / 1$ の塩酸を添加した後, $25^{\circ} \mathrm{C}$ の恒温室で 24 時間振 とうした。土㙵と溶液を遠心分離 (3,500 rpm, 10分間) した後, ポアサイズ $0.45 \mu \mathrm{m}$ のディスミックフィルター で上澄み液をろ過した。実験前後の $\mathrm{SO}_{4}{ }^{2-}$ 濃度から, 土壤の $\mathrm{SO}_{4}{ }^{2-}$ 吸着量を求め, 土壤 $100 \mathrm{~g}$ あたりのミリ当 量で表して( $\mathrm{ANC}) \mathrm{a}$ とした。 $\mathrm{SO}_{4}{ }^{2-}$ の定量にはイオンク ロマトグラフ法を用いた。

\section{3. $4 \mathrm{ANC}$ 算出法}

植物に有害なアルミニウムイオンの濃度が上昇し始め る土壤流出水 $\mathrm{pH}$ 環境被害抑制の限度として考えるこ とができる。佐藤・大岸6) はこのpHを4.7とし, 流出水 の $\mathrm{pH}$ が4.7になるまでに土壤が消費した $\mathrm{H}^{+}$量をこの土
壤の中和能として定義している。ANCは, 中和に関与 する炭酸塩と交換性塩基の総量 $(\mathrm{ANC}) \mathrm{c}$ と, 配位子交換 しうる $\mathrm{OH}^{-}$量を(ANC) a を用い, 次式により算出する ことが可能である。

$$
\begin{aligned}
& \mathrm{ANC}=(\mathrm{ANC}) \mathrm{c} /(1-\alpha) \quad(\alpha<\beta \text { の場合 }) \cdots \cdots(1) \\
& \mathrm{ANC}=(\mathrm{ANC}) \mathrm{a}+(\mathrm{ANC}) \mathrm{c} \quad(\beta>\alpha \text { の場合 }) \cdots \cdots(2)
\end{aligned}
$$
量分率 (平成 4 年度の仙台市郊外で採取した降水 ${ }^{11}$ を もとに算出した）であり， $\beta$ は次式により算出した。

$$
\beta=(\mathrm{ANC}) \mathrm{a} /\{(\mathrm{ANC}) \mathrm{a}+(\mathrm{ANC}) \mathrm{c}\}
$$

\section{4 統計解析}

$\mathrm{n}$ 個の成分の測定值からなる数值群パターンを $\mathrm{n}$ 次元 空間の位置ベクトルとして考えると, $\mathrm{A}\left(\mathrm{a}_{1}, \mathrm{a}_{2}, \underset{\rightarrow}{\rightarrow}, \mathrm{a}_{\mathrm{n}}\right) \underset{\rightarrow}{\text { と }}$ $\mathrm{B}\left(\mathrm{b}_{1}, \mathrm{~b}_{2}, \cdots, \mathrm{b}_{\mathrm{n}}\right)$ との間のパターンの類似性は $\overrightarrow{\mathrm{OA}}$ と $\overrightarrow{\mathrm{OB}}$ のなす角度によって数値化できる。ベクトルの内積より 次式が得られる。

$\mathrm{P}$ (パターン類似率)

$$
=\cos \theta=\frac{(\overrightarrow{\mathrm{OA}}, \overrightarrow{\mathrm{OB}})}{|\mathrm{OA}| \cdot|\mathrm{OB}|}=\frac{\Sigma\left(\mathrm{a}_{\mathrm{i}} \cdot \mathrm{b}_{\mathrm{i}}\right)}{\Sigma \mathrm{a}_{1}{ }^{2} \cdot \Sigma \mathrm{b}_{\mathrm{i}}{ }^{2}}
$$

したがって, 数值群 $\mathrm{A}$ と Bが互いに類似しているも 
のほど，パターン類似率は1.0に近くなる ${ }^{12)}$ 。今回は， ベクトル A に平成 4 年度に仙台市郊外で観測された降 水 ${ }^{11)}$ の陽イオン成分を, ベクトル Bに ANC算出時に測 定した土壤の水溶性陽イオンをそれぞれあてはめ，パ ターン類似率を算出した。

\section{3. 結果および考察}

各土壌の $\mathrm{pH}\left(\mathrm{H}_{2} \mathrm{O}\right)$, EC およびパ夕ーン類似率を表 2 に示した。調査した 15 の土壤型の $\mathrm{pH}\left(\mathrm{H}_{2} \mathrm{O}\right)$ は 4.5 から 7.5 の範囲にあった。口田ら ${ }^{13)}$ は平成 4 年度に今回の調 査地点とほぼ同一な 5 地点において $\mathrm{pH}, \mathrm{EC}$ などの調査 を行っているが，今回の測定結果は 1 年前のそれと比較 しほぼ同じレベルにあった。藤澤ら ${ }^{14)}$ は石川県におい て，酸性雨の影響を予測するための土壤モニタリング調 查を実施している。その中で，平成元年度と 4 年度にお いて調査した 4 力所での測定結果は，よく似た傾向を示 しており，3 年間で土壤に大きな変化はなかったことを 報告しており，今回の結果と一致した。古明地ら ${ }^{15)}$ は, 土壤化学成分の垂值分布を調查しており, $\mathrm{pH}$ は表層が 低く, 下層で上昇する傾向を報告している。このパター ンは酸性降下物の影響を受ける地点における一般的なも のであるが, 今回の結果では「荒井」, 芋沢北」および「野 村」を除いた13地点で同様の傾向が認められた。加藤 $ら^{16)}$ は日光スギ並木林下においてはスギの落葉・落枝 に由来すると考えられる有機物の蓄積による酸基の増体 と塩基の蓄積とは相殺の関係にあり, $\mathrm{pH}$ の上昇が抑え られることを報告している。「芋沢北」および「野村」 は神社境内のスギ林において土壤試料を採取しており, スギ由来の有機物の蓄積が $\mathrm{pH}$ 低下を防いでいるもの と思われる。

各土壤のパターン類似率は, (1)いずれの層においても 低い值を示すグループ (定禅寺)，(2)表層において低い 值を示すグループ (大倉, 芋沢北, 熊ケ根, 芋沢西, 野 村，北山および赤沼)，(3)いずれの層においても高い值 を示すグループ (蕃山, 権現森, 青葉山, 坪沼, 深沼, 荒井および霞の目）の3つのグループに大別された。ま た，下層においては造成土である「定禅寺」を除き，す ベての土壤で雨の陽イオン組成に近い值が認められた。 無機質層である下層の陽イオン組成が，多くの種類の土 壤でほぼ同一の值を示したことは注目に值する。

各土壌の ( ANC) a, ( ANC) c およびANCを表 3 に示 した。調查した仙台市の代表的土壤の ANCは0.1から $33.9 \mathrm{meq} / 100 \mathrm{~g}$ (平均 $13.2 \mathrm{meq} / 100 \mathrm{~g}$ ) であった。また, すべての土壤試料において, ANCは (2) 式を用いて 算出した。また, アルミニウムイオンの溶脱に最も影響 を与える表層におけるANCの範囲は1.2から $29.5 \mathrm{meq} / 100 \mathrm{~g}$ (平均 $14.3 \mathrm{meq} / 100 \mathrm{~g}$ ) の範囲にあった。 最も低いANCを示した土壤型は「深沼」(海岸)より採
取した砂丘未熟土であり, 反対に最も高いANCを示し たものは「芋沢北」より採取した成黄色土であった。

算出したANCは，土壤の酸性降下物に対する耐久性 を評価可能な指標である。そこで, 各土壤の ANCを基 準として, 次式により土壤流出水のpHが4.7となるまで の所用年数を算出した。

$$
\begin{aligned}
& \text { 所用年数 }=\mathrm{ANC} / \mathrm{H}^{+} \text {の } 1 \text { 年間の降下量 } \\
& \left(\mathrm{meq} / \mathrm{m}^{2}\right) \times 1000
\end{aligned}
$$

算出にあたっては, (1)平成 4 年度に仙台市で観測され た降水が今後も継続する, (2)土壤の比重を $1.0 \mathrm{~g} / \mathrm{cm}^{3}$ と する, (3)評価対象とする土壤の深さを地表面より $10 \mathrm{~cm}$ とする, (4)鉱物の風化および生物活動による土壤の中和 作用を考慮しない, の 4 条件を仮定した。式中にある係 数(1000)は, $1 \mathrm{~m}^{2} \times 10 \mathrm{~cm}$ の土壤の重量を ANCの単位で ある $100 \mathrm{~g}$ で除したものである。その結果, 土壤からの 流出水の $\mathrm{pH}$ が 4.7 にまで低下する推定年数は 64 年から 1750年 (平均740年) の範囲にあり, 土壤型によりかな りのばらつきがあることがわかった。本方法は炭酸塩, 交換性塩基による中和反応および陰イオンの土壤吸着反 応に基づく土壤中和能を評価したものであり，土壤の状 態に関する長期的な変化を一予測するためには, 反忍は遅 いが中和容量の大きい鉱物の風化の寄与を考慮する必要 があることが指摘されている 壤の中和に奇与していることから, 今回得られた土壤中 和能は, 現実の $\mathrm{H}^{+}$許容量を過小評価していることを留 意しなければならない。

佐藤・大岸 ${ }^{6)}$ は同一の土壤型（褐色森林土）でも ANCは地域によって10倍の, 黒ぼく土についても 1 桁 の差が認められたことを報告している。したがって，酸 性雨の土壌あるいは植物への影響の現状把握や将来予測 を行う上において，それぞれの地域ごとに土壤中和能を 測定することが不可欠である。今回得られた 15 土壤型に 関する土壤中和能の測定は, 地域を仙台市内と特定した ものであり，その地域における酸性雨の現実的な影響を 予測するための重要なデー夕となるであろう。また，土 壤中和能の低い地域における土壤の化学的性質および植 物の状態を定期的にモニタリング調査することは, 酸性 雨の生態への悪影響を末然に察知することを可能とし, 効果的な予防対策となると考えられる。

\section{謝 辞}

本研究を遂行するにあたり，有益なご助言をいただい た東北大学農学部南條正巳先生, 木村和彦先生に感謝の 意を表する。

\section{要 約}

仙台市内に比較的広範に存在する 15 種類の土壌型につ 
Table $2 \mathrm{pH}, \mathrm{EC}$ and pattern resembling rate of each soil

\begin{tabular}{|c|c|c|c|c|c|}
\hline $\begin{array}{l}\text { Monitoring } \\
\text { point }\end{array}$ & $\begin{array}{l}\text { Layer } \\
\text { No. }\end{array}$ & $\begin{array}{l}\text { Height of } \\
\text { layer }(\mathrm{cm})\end{array}$ & $\mathrm{pH}\left(\mathrm{H}_{2} \mathrm{O}\right)$ & $\begin{array}{c}\mathrm{EC} \\
\mu \mathrm{S} / \mathrm{cm}\end{array}$ & $\begin{array}{l}\text { Pattern } \\
\text { res. rate }\end{array}$ \\
\hline Jozenji & $\begin{array}{l}1 \\
2 \\
3 \\
-\end{array}$ & $\begin{array}{c}0 \sim 5 \\
5 \sim 30 \\
30 \sim\end{array}$ & $\begin{array}{r}6.03 \\
6.50 \\
7.54 \\
-\end{array}$ & $\begin{array}{r}82.3 \\
79.2 \\
-193.3\end{array}$ & $\begin{array}{r}0.45 \\
0.53 \\
0.46\end{array}$ \\
\hline Banzan & $\begin{array}{l}1 \\
2 \\
.\end{array}$ & $\begin{array}{r}2 \sim 22 \\
22 \sim 66\end{array}$ & $\begin{array}{r}4.92 \\
5.10\end{array}$ & $\begin{array}{r}29.0 \\
20.0\end{array}$ & $\begin{array}{r}0.95 \\
0.95 \\
-\end{array}$ \\
\hline Gongenmori & $\begin{array}{l}1 \\
2 \\
3 \\
-\end{array}$ & $\begin{array}{l}0 \sim 18 \\
18 \sim 46 \\
46 \sim\end{array}$ & $\begin{array}{l}5.03 \\
5.18 \\
5.33\end{array}$ & $\begin{array}{l}22.7 \\
29: 1 \\
24.2\end{array}$ & $\begin{array}{l}0.99 \\
0.98 \\
0.98\end{array}$ \\
\hline Aobayama & $\begin{array}{l}1 \\
2 \\
3 \\
-.\end{array}$ & $\begin{array}{r}0 \sim 19 \\
19 \sim 54 \\
54 \sim 80\end{array}$ & $\begin{array}{l}5.08 \\
5.17 \\
5.14 \\
-.9\end{array}$ & $\begin{array}{r}31.4 \\
26.9 \\
27.5\end{array}$ & \begin{tabular}{l}
0.99 \\
0.99 \\
0.98 \\
\hdashline
\end{tabular} \\
\hline Ohkura & $\begin{array}{l}1 \\
2 \\
3 \\
-\end{array}$ & $\begin{array}{r}5 \sim 22 \\
22 \sim 44 \\
44 \sim 66\end{array}$ & $\begin{array}{l}5.43 \\
5.54 \\
5.68 \\
\end{array}$ & $\begin{array}{r}110.2 \\
34.4 \\
30.1 \\
\end{array}$ & $\begin{array}{l}0.63 \\
0.99 \\
0.99\end{array}$ \\
\hline Tsubonuma & $\begin{array}{r}1 \\
2 \\
-\end{array}$ & $\begin{array}{c}0 \sim 50 \\
50 \sim 100\end{array}$ & $\begin{array}{r}5.39 \\
5.58 \\
-\end{array}$ & $\begin{array}{r}23.5 \\
16.0 \\
\end{array}$ & $\begin{array}{l}0.95 \\
0.93\end{array}$ \\
\hline Imozawakita & $\begin{array}{l}1 \\
2 \\
3 \\
4\end{array}$ & $\begin{array}{c}0 \sim 8 \\
8 \sim 25 \\
25 \sim 42 \\
42 \sim\end{array}$ & $\begin{array}{l}5.50 \\
5.14 \\
5.04 \\
5.00\end{array}$ & $\begin{array}{r}255.0 \\
35.7 \\
28.6 \\
34.0\end{array}$ & $\begin{array}{l}0.40 \\
0.71 \\
0.93 \\
0.94\end{array}$ \\
\hline Fukanuma & $\begin{array}{l}1 \\
2 \\
3 \\
4 \\
-\end{array}$ & $\begin{array}{l}2 \sim 12 \\
12 \sim 19 \\
19 \sim 26 \\
26 \sim 100 .\end{array}$ & $\begin{array}{l}5.37 \\
6.34 \\
6.44 \\
6.63 \\
\end{array}$ & $\begin{array}{r}97.9 \\
29.3 \\
37.9 \\
28.6\end{array}$ & $\begin{array}{l}0.98 \\
0.98 \\
0.98 \\
0.97\end{array}$ \\
\hline Kumagane & $\begin{array}{r}1 \\
2 \\
3 \\
-\end{array}$ & $\begin{array}{c}3 \sim 8 \\
8 \sim 48 \\
48 \sim\end{array}$ & $\begin{array}{r}5.30 \\
5.26 \\
5.44 \\
-\end{array}$ & $\begin{array}{r}232.0 \\
89.8 \\
\quad 44.1 \\
\end{array}$ & $\begin{array}{l}0.47 \\
0.70 \\
0.94\end{array}$ \\
\hline Imozawanishi & $\begin{array}{l}1 \\
2 \\
3 \\
4 .\end{array}$ & $\begin{array}{c}0 \sim 2 \\
2 \sim 12 \\
12 \sim 25 \\
25 \sim 70\end{array}$ & $\begin{array}{l}4.30 \\
4.88 \\
5.41 \\
5.13\end{array}$ & $\begin{array}{r}142.2 \\
111.6 \\
56.0 \\
64.6\end{array}$ & $\begin{array}{l}0.58 \\
0.89 \\
0.93 \\
0.88\end{array}$ \\
\hline Nomura & $\begin{array}{l}1 \\
2 \\
3 \\
4\end{array}$ & $\begin{array}{c}0 \sim 4 \\
4 \sim 37 \\
37 \sim 58 \\
58 \sim 77\end{array}$ & $\begin{array}{l}5.69 \\
5.32 \\
5.35 \\
5.32\end{array}$ & $\begin{array}{r}357.0 \\
58.3 \\
43.1 \\
53.1 \\
\end{array}$ & $\begin{array}{l}0.44 \\
0.93 \\
0.98 \\
0.98\end{array}$ \\
\hline Arai & $\begin{array}{l}1 \\
2 \\
.\end{array}$ & $\begin{array}{c}0 \sim 30 \\
30 \sim 100\end{array}$ & $\begin{array}{r}5.89 \\
5.19 \\
-\end{array}$ & $\begin{array}{r}87.4 \\
.44 .2\end{array}$ & $\begin{array}{l}0.93 \\
0.95\end{array}$ \\
\hline Kitayama & $\begin{array}{l}1 \\
2 \\
-\end{array}$ & $\begin{array}{c}4 \sim 17 \\
17 \sim\end{array}$ & $\begin{array}{r}4.45 \\
-4.79 \\
-\end{array}$ & $\begin{array}{r}111.6 \\
45.7\end{array}$ & $\begin{array}{r}0.65 \\
0.98\end{array}$ \\
\hline Akanuma & $\begin{array}{l}1 \\
2 \\
3 \\
4\end{array}$ & $\begin{array}{l}0 \sim 18 \\
18 \sim 37 \\
37 \sim 80 \\
80 \sim\end{array}$ & $\begin{array}{l}5.22 \\
5.29 \\
5.58 \\
5.69\end{array}$ & $\begin{array}{r}71.9 \\
66.1 \\
61.5 \\
69.1 \\
\end{array}$ & $\begin{array}{l}0.39 \\
0.63 \\
0.92 \\
0.84\end{array}$ \\
\hline Kasuminome & $\begin{array}{l}1 \\
2\end{array}$ & $\begin{array}{r}0 \sim 20 \\
20 \sim 35\end{array}$ & $\begin{array}{l}4.90 \\
6.13\end{array}$ & $\begin{array}{r}85.3 \\
117.5\end{array}$ & $\begin{array}{l}0.93 \\
0.99\end{array}$ \\
\hline
\end{tabular}


Table 3 The ANC of each soil in Sendai City

\begin{tabular}{|c|c|c|c|c|c|}
\hline Monitoring & $\begin{array}{l}\text { Layer } \\
\text { No. }\end{array}$ & $\begin{array}{l}\text { Height of } \\
\text { layer }(\mathrm{cm})\end{array}$ & $\begin{array}{c}(\mathrm{ANC}) \mathrm{a} \\
\mathrm{meq} / 100 \mathrm{~g}\end{array}$ & $\begin{array}{c}(\mathrm{ANC}) \mathrm{c} \\
\mathrm{meq} / 100 \mathrm{~g}\end{array}$ & $\begin{array}{c}\text { ANC } \\
\text { meq } / 100 \mathrm{~g}\end{array}$ \\
\hline Jozenji & $\begin{array}{l}1 \\
2 \\
3 \\
-\end{array}$ & $\begin{array}{c}0 \sim 5 \\
5 \sim 30 \\
30 \sim\end{array}$ & $\begin{array}{l}\text { N.D. } \\
1.10 \\
0.67\end{array}$ & $\begin{array}{l}12.86 \\
17.29 \\
26.17\end{array}$ & $\begin{array}{r}12.9 \\
18.4 \\
26.8 \\
-\end{array}$ \\
\hline Banzan & $\begin{array}{r}1 \\
2 \\
.\end{array}$ & $\begin{array}{r}2 \sim 22 \\
22 \sim 66 .\end{array}$ & $\begin{array}{l}2.13 \\
0.25\end{array}$ & $\begin{array}{r}5.99 \\
19.66 \\
\end{array}$ & $\begin{array}{r}8.1 \\
19.9 \\
\end{array}$ \\
\hline Gongenmori & $\begin{array}{r}1 \\
2 \\
3 \\
. .\end{array}$ & $\begin{array}{l}0 \sim 18 \\
18 \sim 46 \\
46 \sim\end{array}$ & $\begin{array}{r}1.76 \\
2.87 \\
3.44\end{array}$ & $\begin{array}{r}5.03 \\
7.72 \\
11.14\end{array}$ & $\begin{array}{r}6.8 \\
10.6 \\
14.6 \\
-\end{array}$ \\
\hline Aobayama & $\begin{array}{l}1 \\
2 \\
3 \\
-.\end{array}$ & $\begin{array}{r}0 \sim 19 \\
19 \sim 54 \\
54 \sim 80\end{array}$ & $\begin{array}{l}3.08 \\
2.18 \\
3.14\end{array}$ & $\begin{array}{r}8.15 \\
11.84 \\
15.35 \\
-1\end{array}$ & $\begin{array}{l}11.2 \\
14.0 \\
18.5\end{array}$ \\
\hline Okura & $\begin{array}{r}1 \\
2 \\
3 \\
. .\end{array}$ & $\begin{array}{r}5 \sim 22 \\
22 \sim 44 \\
44 \sim 66\end{array}$ & $\begin{array}{l}1.17 \\
1.49 \\
1.32\end{array}$ & $\begin{array}{l}28.31 \\
27.24 \\
22.86\end{array}$ & $\begin{array}{r}29.5 \\
28.7 \\
24.2\end{array}$ \\
\hline Tsubonuma & $\begin{array}{l}1 \\
2 .\end{array}$ & $\begin{array}{c}0 \sim 50 \\
50 \sim 100\end{array}$ & $\begin{array}{l}3.13 \\
3.02\end{array}$ & $\begin{array}{r}7.27 \\
7.76 \\
\end{array}$ & $\begin{array}{r}10.4 \\
10.8\end{array}$ \\
\hline Imozawakita & $\begin{array}{l}1 \\
2 \\
3 \\
4 .\end{array}$ & $\begin{array}{c}0 \sim 8 \\
8 \sim 25 \\
25 \sim 42 \\
42 \sim\end{array}$ & $\begin{array}{l}0.51 \\
0.87 \\
\text { N.D. } \\
0.85\end{array}$ & $\begin{array}{r}33.40 \\
5.83 \\
5.76 \\
4.22 \\
.\end{array}$ & $\begin{array}{r}33.9 \\
6.7 \\
5.8 \\
5.1 \\
\end{array}$ \\
\hline Fukanuma & $\begin{array}{l}1 \\
2 \\
3 \\
4 \\
-\end{array}$ & $\begin{array}{l}2 \sim 12 \\
12 \sim 19 \\
19 \sim 26 \\
26 \sim 100\end{array}$ & $\begin{array}{l}\text { N.D. } \\
0.11 \\
\text { N.D. } \\
\text { N.D. }\end{array}$ & $\begin{array}{l}1.17 \\
1.60 \\
0.87 \\
0.43\end{array}$ & $\begin{array}{l}1.2 \\
1.7 \\
0.9 \\
0.4\end{array}$ \\
\hline Kumagane & $\begin{array}{r}1 \\
2 \\
3 \\
-\end{array}$ & $\begin{array}{c}3 \sim 8 \\
8 \sim 48 \\
48 \sim\end{array}$ & $\begin{array}{l}\text { N.D. } \\
\text { N.D. } \\
0.33\end{array}$ & $\begin{array}{r}25.06 \\
23.01 \\
2.85 \\
\end{array}$ & $\begin{array}{r}25.1 \\
23.0 \\
3.2 \\
\end{array}$ \\
\hline Imozawanishi & $\begin{array}{l}1 \\
2 \\
3 \\
4 .\end{array}$ & $\begin{array}{c}0 \sim 2 \\
2 \sim 12 \\
12 \sim 25 \\
25 \sim 70\end{array}$ & $\begin{array}{l}\text { N.D. } \\
\text { N.D. } \\
\text { N.D. } \\
\text { N.D. }\end{array}$ & $\begin{array}{l}14.08 \\
16.51 \\
10.06 \\
12.84\end{array}$ & $\begin{array}{l}14.1 \\
16.5 \\
10.1 \\
12.8\end{array}$ \\
\hline Nonura & $\begin{array}{l}1 \\
2 \\
3 \\
4 \\
-\end{array}$ & $\begin{array}{c}0 \sim 4 \\
4 \sim 37 \\
37 \sim 58 \\
58 \sim 77\end{array}$ & $\begin{array}{l}0.55 \\
0.32 \\
0.67 \\
0.83\end{array}$ & $\begin{array}{l}28.45 \\
12.26 \\
13.66 \\
16.94\end{array}$ & $\begin{array}{l}29.0 \\
12.6 \\
14.3 \\
17.8\end{array}$ \\
\hline Arai & $\begin{array}{r}1 \\
2 \\
-\end{array}$ & $\begin{array}{c}0 \sim 30 \\
30 \sim 100\end{array}$ & $\begin{array}{l}\text { N.D. } \\
\text { N.D. }\end{array}$ & $\begin{array}{r}10.29 \\
6.58\end{array}$ & $\begin{array}{r}10.3 \\
6.6 \\
\end{array}$ \\
\hline Kitayama & $\begin{array}{r}1 \\
2 \\
.\end{array}$ & $\begin{array}{c}4 \sim 17 \\
17 \simeq\end{array}$ & $\begin{array}{l}\text { N.D. } \\
3.07\end{array}$ & $\begin{array}{r}2.31 \\
0.06 \\
\end{array}$ & $\begin{array}{r}2.3 \\
0.1 \\
\end{array}$ \\
\hline Akanuma & $\begin{array}{l}1 \\
2 \\
3 \\
4 \\
-\end{array}$ & $\begin{array}{r}0 \sim 18 \\
18 \sim 37 \\
37 \sim 80 \\
80 \sim\end{array}$ & $\begin{array}{l}\text { N.D. } \\
\text { N.D. } \\
\text { N.D. } \\
0.31\end{array}$ & $\begin{array}{r}7.18 \\
8.13 \\
13.24 \\
0.74 \\
\end{array}$ & $\begin{array}{r}7.2 \\
8.1 \\
13.2 \\
1.0 \\
\end{array}$ \\
\hline Kasuminome & $\begin{array}{l}1 \\
2\end{array}$ & $\begin{array}{r}0 \sim 20 \\
20 \sim 35\end{array}$ & $\begin{array}{l}\text { N.D. } \\
\text { N.D. }\end{array}$ & $\begin{array}{l}12.76 \\
30.81\end{array}$ & $\begin{array}{l}12.8 \\
30.8\end{array}$ \\
\hline
\end{tabular}

N.D.: $0.01 \mathrm{meq} / 100 \mathrm{~g}$ 
いて，それぞれの土哄中和能をバッチ法により測定し， 本市に扔ける酸性雨による被害の予測を試みた。測定項 目は土壤の $\mathrm{pH}$ および $\mathrm{EC}$ ならびに酸中和能( $\mathrm{ANC}$ ) であ る。酸中和能は土壤流出水の $\mathrm{pH}$ が4.7に低下するまで に，土壤が消費する $\mathrm{H}^{+}$量として定義される。また，各 土壤の水溶性陽イオンの組成比をパターン類似率を指標 として比較した。調查した 15 の土壤型の $\mathrm{pH}\left(\mathrm{H}_{2} \mathrm{O}\right)$ は 4.5 から 7.5 の範囲にあった。各土壤の下層におけるパ 夕ーン類似率は，造成土である「定禅寺」を除き，すべ ての土壤で雨の陽イオン組成に近い值が認められた。調 查した土䁃の ANCは 0.1 から $33.9 \mathrm{meq} / 100 \mathrm{~g}$ (平均 $13.2 \mathrm{meq} / 100 \mathrm{~g})$ であった。また，表層におけるANCの 範囲は 1.2 加 $29.5 \mathrm{meq} / 100 \mathrm{~g}$ （平均 $14.3 \mathrm{meq} / 100 \mathrm{~g}$ ）の範 囲にあり，最も低いANC を示した土㙵型は「深沼」（海 岸）より採取した砂丘未熟土であり，反対に最も高い ANCを示したものは「芋沢北」より採取した灰黄色土 であった。

\section{文 献}

1) Tamm, C.O.: Acid precipitation; Biological effects in soil and on forest vegetation.AMBIO. 5, 235-238 (1976)

2）環境庁水質保全局監修：酸性雨，土壤・植生への影 響, pp.12-50, 公害研究対策センター, 東京 (1990)

3) Glass,N.R., Glass.E and Rennie.P.J: Effects of acid precipitation.Environ. Sci. Technol., 13, 1350-1355 (1979)

4) Cole D.W., and Johnson.D.W: Atmospheric sulfate additions and cation leaching in a Douglas fir ecosystem, Water Resour. Res., 13, 313-317(1977)

$5 ）$ 環境庁水質保全局監修：酸性雨，土壤・植生への影 響, pp.12-50, 公害研究対策センター, 東京(1990)

6）佐藤一男, 大岸弘：酸性降下物に対する土壤中和能 の簡易測定法, 環境科学会誌，3，37-48(1990)
7) Sato K. and Ohkishi.H: Rapid Acid -neutralizing capacity of surface soils in Japan. AMBIO, 22, 232-235(1993)

8）経済企画庁：土地分類基本調査汹 (国土調査)第72 号, 土壤四 (仙台), 1967

9）宮城県：土地分類基本調査図（都道府県土地分類基 本調査), 土壤図 (川崎・山形), 1986

10）土壤標準分析・測定法委員会編「土潩標準分析・測 定法」, pp.70-76, 博友社, 東京 (1986)

11）口田寺吾, 東海敬‥, 千葉 恵, 玉川勝美, 加藤丈 夫, 関 敏彦, 東海香, 佐々木政光, 伊藤善通: ろ過式採取法による仙台市における酸性雨の実態調 査，仙台市衛生研究所報，22，303-313(1992)

12 ）玉川勝美，相原良之，大金由夫，加藤恵，広島紀以 子, 三島靖子, 関敏彦, 角田行, 泉田三郎, 阿部克 己, 伊藤善通, 国井清, 回谷教男: 低沸点有機塩素 化合物による環境水污染 (第 2 報)一河川水拉よび 地下水の污染事例一, 仙台市衛生試験所報, 13, 275-286( 1983)

13) 口田圭吾, 東海敬一, 千葉 恵, 玉川勝美, 加藤丈 夫，関敏彦：酸性雨が土壤に及ぼす影響について， 仙台市衛生研究所報, 22,314-317(1992)

14）藤澤明子, 森島敏明, 西川孝蔵, 清水憲次, 小西秀 則, 山上信明，本田和子，四手井英一，千木容，小 谷二郎：石川県における酸性雨土壤モニタリング調 査, 石川県保健環境センター年報, 30, 331-342(1993)

15）古明地哲人, 鈴木光春, 栗本哲男, 川瀬祐司, 門井 守夫：大気降下物と土壤中化学成分の挙動（1）, 東京都環境科学研究所年報, 18-24(1990)

16）加藤秀正, 澤田智志，薄井宏：日光スギ並木林下の 土壌の塩基の蓄積, 日本土壤肥料学雑誌, 60 , 358-365(1989)

17）佐藤一男：酸性雨の土壤による中和, 資源環境対策, 28, 547-553(1992) 